\title{
Why do recent graduates enter into flexible jobs?
}

Citation for published version (APA):

Bertrand-Cloodt, D. A. M., Cörvers, F., Kriechel, B., \& van Thor, J. A. F. (2011). Why do recent graduates enter into flexible jobs? Researchcentrum voor Onderwijs en Arbeidsmarkt, Faculteit der Economische Wetenschappen. ROA Research Memoranda No. 10 https://doi.org/10.26481/umaror.2011010

Document status and date:

Published: 01/01/2011

DOI:

10.26481/umaror.2011010

Document Version:

Publisher's PDF, also known as Version of record

\section{Please check the document version of this publication:}

- A submitted manuscript is the version of the article upon submission and before peer-review. There can be important differences between the submitted version and the official published version of record.

People interested in the research are advised to contact the author for the final version of the publication, or visit the DOI to the publisher's website.

- The final author version and the galley proof are versions of the publication after peer review.

- The final published version features the final layout of the paper including the volume, issue and page numbers.

Link to publication

\footnotetext{
General rights rights.

- You may freely distribute the URL identifying the publication in the public portal. please follow below link for the End User Agreement:

www.umlib.nl/taverne-license

Take down policy

If you believe that this document breaches copyright please contact us at:

repository@maastrichtuniversity.nl

providing details and we will investigate your claim.
}

Copyright and moral rights for the publications made accessible in the public portal are retained by the authors and/or other copyright owners and it is a condition of accessing publications that users recognise and abide by the legal requirements associated with these

- Users may download and print one copy of any publication from the public portal for the purpose of private study or research.

- You may not further distribute the material or use it for any profit-making activity or commercial gain

If the publication is distributed under the terms of Article $25 \mathrm{fa}$ of the Dutch Copyright Act, indicated by the "Taverne" license above, 


\section{Why do recent graduates enter into flexible jobs?}

Daniëlle Bertrand-Cloodt

Frank Cörvers

Ben Kriechel

Jesper van Thor

\section{ROA Research Memorandum}

ROA-RM-2011/10

Research Centre for Education and the Labour Market Maastricht University

P.O. Box 616,6200 MD Maastricht, The Netherlands

$\mathrm{T}+31433883647 \mathrm{~F}+31433884914$

secretary-roa-sbe@maastrichtuniversity.n www.roa.nl 


\title{
Why do recent graduates enter into flexible jobs?
}

\author{
Daniëlle Bertrand-Cloodt \\ Frank Cörvers \\ Ben Kriechel \\ Jesper van Thor
}

ROA-RM-2011/10*

October 2011

Research Centre for Education and the Labour Market

Maastricht University

P.O. Box 616, 6200 MD Maastricht, The Netherlands

$\mathrm{T}+31433883647 \mathrm{~F}+31433884914$

secretary-roa-sbe@maastrichtuniversity.nl

www.roa.nl

\footnotetext{
* The ROA Research Memorandum Series was created in order to make research results available for discussion, before those results are submitted for publication in journals.
} 


\section{Abstract}

\section{Why do recent graduates enter into flexible jobs?}

The share of flexible jobs on the Dutch labour market is among the highest in Western countries, in particular for recent graduates. In this study we examine why recent graduates enter into temporary contracts and whether flexible jobs match their qualifications worse than permanent jobs do. Graduates that enter into flexible jobs face large wage penalties, a worse job match and less training participation than those entering into permanent jobs, even after correcting for ability differences. When the labour market situation for a particular field of education deteriorates, a larger share of recent graduates is forced into flexible jobs, which may threaten their position on the labour market in the long run. Flexible work among graduates is unrelated to their willingness to take risks. Only for university graduates are there any indications that flexible jobs may provide stepping stones to permanent jobs.

JEL classification: J21, J24, J41, M51

Keywords: Flexible work; job characteristics; job mismatch ; temporary contracts; recent graduates; willigness to take risks

\section{Daniëlle Bertrand-Cloodt \\ ROA \\ Postbus 616 \\ NL-6200 MD Maastricht \\ The Netherlands \\ dam.cloodt@maastrichtuniversity.nl}

Ben Kriechel

ROA

Postbus 616

NL-6200 MD Maastricht

The Netherlands

ben.kriechel@maastrichtuniversity.nl

and Institute for Study of Labor (IZA), Bonn
Frank Cörvers

ROA

Postbus 616

NL-6200 MD Maastricht

The Netherlands

frank.corvers@maastrichtuniversity.nl

and Meteor, NSI and Netspar

Jesper van Thor

ROA

Postbus 616

NL-6200 MD Maastricht

The Netherlands

j.vanthor@maastrichtuniversity.nl 


\section{Introduction}

Flexible work arrangements are generally regarded as good for employers. If companies are faced with declining demand for products or poorly performing employees, the expiration of labour contracts of fixed-term employees is a cheap way to get rid of personnel since it is excluded from all redundancy procedures and severance pay companies have to face when firing permanent workers. Moreover, temporary employment agencies supply workers on short notice, which makes it possible for companies to adjust their workforce quickly.

However, on the supply side of the labour market the advantages of flexible work are ambiguous. On the one hand, several empirical studies find evidence for short job spells, bad pay and working conditions of flexible jobs ${ }^{1}$ relative to permanent jobs. For the medium and long term, the unemployed might be better off to invest in further job search to find a permanent job rather than accepting a temporary job (Autor and Houseman, 2005, 2010; Houseman and Polivka, 2000). On the other hand, some studies find more positive results on long term labour market performance for those who accept a temporary job. The differences with respect to wage compensation (Addison and Surfield, 2007) and employment continuity (Addison and Surfield, 2009a, 2009b) between those who find a permanent job and those who initially have to accept a temporary job seems to dissipate in the long run.

Temporary employment is very common in the Netherlands. ${ }^{2}$ This may give rise to some worries, in particular for recent graduates. They could, relative to older job seekers, benefit most from a first job with a large learning content, and from much attention at the work place for training on the job and formal as well as informal learning. When they find a job with a large learning content, they can obtain relevant work experience, acquire essential competencies that make them more attractive for other employers, demonstrate their motivation and capacities and develop their informal network. Even if these jobs are of limited duration, for recent graduates they may serve as a stepping stone toward a permanent job (Booth et al., 2002; Zijl et al., 2004). Therefore, it important to know to what extent recent graduates are exposed to either 'bad' or 'good' jobs, and for what reasons. In the light of the above mentioned empirical studies, recent graduates are appealing to analyse because they are a relatively homogeneous group that hardly differ in labour market experience. Nevertheless, only few studies have examined why recent graduates enter into temporary contracts and whether flexible jobs match their qualifications worse than permanent jobs do, which are the main questions of our paper. What can we conclude from job match indicators on the desirability of flexible jobs for recent graduates? Do flexible jobs offer more or less opportunities to further invest in their careers than permanents jobs? Are there any indications that temporary jobs for recent graduates are stepping stones towards a permanent contract?

In the paper two main categories of flexible jobs among recent graduates are distinguished: direct hire temporary jobs based on fixed-term contracts, and temporary jobs offered by temporary work agencies. Data of recent graduates from Dutch intermediate and higher education is used to analyse the impact of personal characteristics as well as labour market circumstances related to the educational background of the graduates on both the job match and the probability of entering into temporary contracts. First, it is shown that recent graduates in flexible jobs are generally worse off than those in permanent jobs, even after correcting for ability differences. This result is found for several job match indicators, including wage compensation, working in a job that matches educational level and field, participation in training and regret of study choice. Second, personal characteristics like higher ability diminish the probability to enter into temporary contracts, but personal preferences to accept a temporary job hardly play a role. Recent graduates have a higher probability of flexible jobs when they face high unemployment, low attachment to occupations and high employment variation. Third, only at the university level are there any indications that the selection process is different. Some university

\footnotetext{
${ }^{1}$ To indicate all jobs with short-term contracts we refer to flexible rather than atypical or non-standard jobs (see on this topic Dekker, 2007, pp. 173-174).

${ }^{2}$ Temporary employment contracts as a percentage of dependent employment has increased in the Netherlands from about $10 \%$ in 1995 to $18 \%$ in 2009 . The percentage was in 2009 about 4 to $10 \%$ higher than in Denmark, France, Germany and the US (Cörvers et al. 2011, based on OECD figures). For a sample of 13 European countries, the Netherlands exhibits after Spain the highest share of temporary work among higher education graduates in their first job (Allen and Van der Velden, 2007, Table 3.1). Based on Labour Force Survey data for 1999 with respect to reasons for working on a temporary contract (Eurostat, 2000), one may conclude that relative to other countries many employed persons in the Netherlands do not want a permanent job, whereas in Spain they seem to be forced into temporary jobs because of a lack of permanent jobs.
} 
graduates get fixed-term jobs that match their education better than university graduates in permanent jobs, and university graduates with higher grades are more likely to have fixed-term jobs.

The next section discusses the remarkably high incidence of working in flexible contracts by recent graduates relative to the rest of the work force in the Netherlands, as well as the variation over time and the differences between education levels. Section 3 shows to what extent working in fixed-term, temporary agency or permanent jobs is associated to several job match indicators such as wage compensation, training intensity and regret of study choice. In Section 4 we offer a conceptual framework based on a review of the literature as to who enters into flexible contracts and why. We look at explanations concerning both the supply and the demand side of the labour market. Section 5 presents an empirical model to explain the probability of a recent graduate receiving a temporary contract using both personal characteristics and labour market circumstances as explanatory factors. Section 6 draws some conclusions on the costs of contributing to Dutch labour market flexibility borne by recent graduates that enter into flexible jobs.

\section{Flexible Work on the Dutch Labour Market}

In this section the incidence of temporary work among recent graduates is compared to that of the total group of employees in the Dutch labour force. Figure 1a shows the percentage of flexible workers by level of education for employees in the period 1996-2008. We distinguish between upper secondary education (SE) ${ }^{3}$, higher professional education (HPE) ${ }^{4}$ and university education (UE). These data are drawn from the Dutch Labour Force Survey (LFS). For Figure 1b data are drawn from large-scale graduate surveys conducted annually in the Netherlands by the Research Centre for Education and the Labour Market (ROA) 18 months after graduation. A sample of more than 200,000 graduates from 1994/1995 to 2006/2007 graduate cohorts working at least one hour per week remained, excluding apprentices (in upper secondary vocational education) and the small groups of oncall and self-employed workers.

Flexible work is much less common among employees than among recent graduates. This indicates that employees with several years of experience in the labour market have a better labour market position in terms of job security. Figure 1a indicates that the percentage of flexible workers in the labour force diminishes with the level of education. Note that this relationship with educational level does not hold for the percentage of flexible jobs among recent graduates shown in Figure 1b. Of all employees with an HPE diploma, less than 6 percent had a temporary contract in 2008, and of those with a university degree, this percentage was even smaller (3.9 percent). The share of flexible workers among the total group of employees decreased at all education levels after 1998, reached the lowest level around 2003. Thereafter, the share rose again, in particular at the two lower education levels. During the last few years of the period under consideration the share of flexible workers, in particular at the higher levels, declined due to the recovery of the economy. The fluctuations in the percentage of flexible workers are much smaller among the total group of employees than among recent graduates. This indicates that the absorption of the labour market inflow of graduates is particularly important to cope with fluctuations in labour demand caused by the business cycle.

Figure $1 \mathrm{~b}$ suggests that the share of flexible work among recent graduates is cyclical except for university graduates (UE). From 1996 to 2001, continuing economic growth, declining unemployment and a rising number of vacancies increased the bargaining position of recent graduates, and resulted in general in a lower percentage of graduates accepting flexible work positions. When economic growth declines or the economy shrinks, it is cheaper for employers to fire the flexible workforce first. Since Dutch economic growth began to decline in 2001, and remained just above zero in 2002, we can explain the low percentage of flexible work in 2002. The labour market situation dramatically changed during 2002; unemployment rose sharply, peaking at about 6.5 percent in 2004/2005. For graduates of upper secondary education (SE), the percentage of flexible work reached a minimum in 2002, whereas for graduates of higher professional education (HPE), the minimum was reached one year earlier.

The cyclical movement suggests that flexible work among recent graduates primarily functions as a buffer in the workforce to adapt to changes in labour demand. Only for university graduates (UE) did the percentage of

\footnotetext{
${ }^{3}$ This includes upper secondary general HAVO), pre-university general secondary (VWO) and upper secondary vocational education (MBO levels 2, 3, 4 ).

${ }^{4}$ HPE-institutions profile themselves internationally as universities of applied sciences.
} 
flexible jobs remain at a high level - about 50 - during nearly all of the study period. This may indicate that university graduates are more often engaged in temporary contracts for other purposes, like screening and training. University graduates may in particular hold trainee posts at hospitals, traineeships in banks or insurance companies or PhD positions at universities. The share of flexible jobs among university graduates entering the labour market may be therefore less susceptible to business cycle fluctuations than it is among graduates at the lower education levels.

\section{Figure 1}

Percentage of flexible workers among employees in the labour force (1a) and recent graduates (1b) in paid employment by level of education, 1996-2008

1a Employees

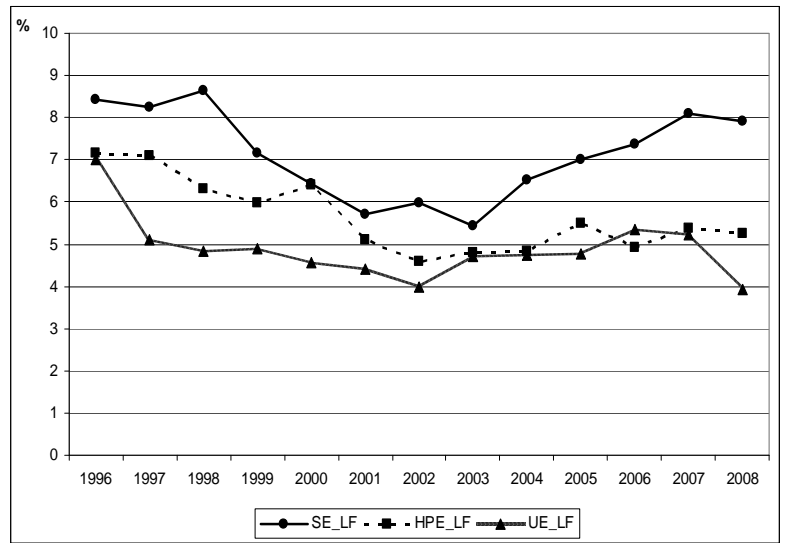

1b Recent Graduates

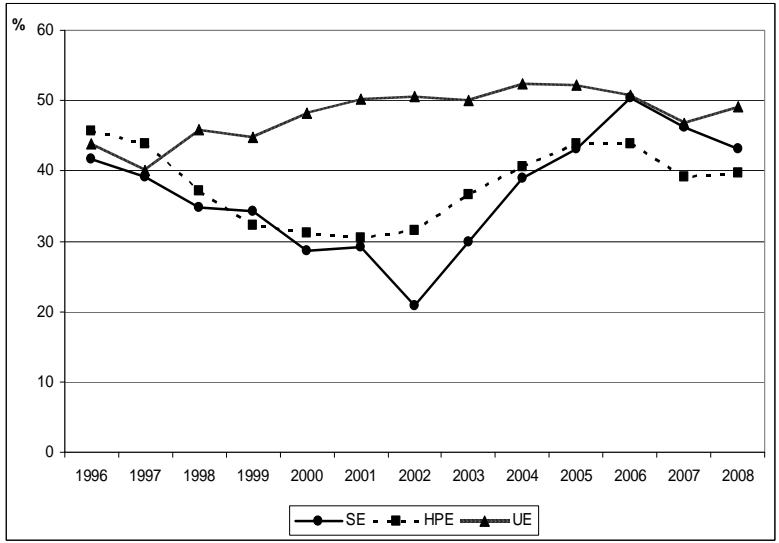

Sources: Statistics Netherlands (LFS) and ROA graduates surveys (SIS) for Figure 1a and 1b, respectively.

Notes: $\mathrm{SE}=$ upper secondary education (excl. apprentices); HPE = higher professional education; UE = university education.

\section{Flexible Work and Job Match}

In this section, we examine eight distinct aspects of graduates' jobs to examine the quality of the job match of flexible versus permanent jobs. We use the large-scale graduate surveys conducted annually by the Research Centre for Education and the Labour Market (ROA) 18 months after graduation. The surveys include questions on many different aspects of the education-to-work transition. Extensive information is collected on the graduates' educational background as well as their current job. The information on graduates' current job includes income, hours worked, type of contract and a variety of other indicators of the quality of the job match. To measure the match between education level and current job, the survey uses a self-rating method in which respondents are asked to indicate the education level required and the match between their field of study and their current job. Using logistic regression analyses, we estimate the marginal effect of having a temporary contract on (among others) the probability that graduates work outside their discipline, work part-time or are dissatisfied with their job. The effect of having a flexible contract on log gross hourly wage is estimated with an OLS regression. The analyses in this section are conducted for graduates with a fixed-term contract as well as graduates in temporary agency work. In both analyses, graduates with a permanent contract are the reference group. We conduct separate analyses for each job characteristic for recent graduates of upper secondary education (SE, excl. apprentices), higher professional education (HPE) and university education (UE) for the period between 2002 and $2008^{5}$. We control for gender, ethnicity, age, work region, survey year, level of the course (solely for SE) and final exam result as a proxy for ability. Before discussing the results, note that the marginal effects of temporary contracts on each of the job aspects are not necessarily causal.

\section{Graduates in fixed-term jobs}

Figure 2 shows the impact that a fixed-term contract has on the incidence of several job aspects for graduates of SE, HPE and UE. Upper secondary (SE) graduates with a fixed-term contract work significantly more often

\footnotetext{
${ }^{5}$ For the period before 2002 not all control variables were available.
} 
outside their discipline, in a job below their educational level, and in a part-time job. ${ }^{6}$ They are more often dissatisfied with their job, experience a poorer transition between study and job, regret their choice of study more often and are trained less than SE graduates with a permanent contract. Moreover, the gross hourly wage of SE graduates with a fixed-term contract is 3.2 percent lower than for SE graduates with a permanent contract. We find similar results regarding the impact that a fixed-term contract for higher professional (HPE) graduates has on the job aspects. On average, gross hourly wage is 3.3 percent lower for HPE graduates with a fixed-term rather than a permanent contract.

The results of the logistic regression analysis of university (UE) graduates differ to some extent from the results at the lower educational levels. For UE graduates, the labour market position occasionally seems to be better for employees with a fixed-term contract instead of a permanent contract. UE graduates with a fixed-term contract work less often outside their discipline, are less often overeducated and experience a poor study to job transition less frequently than university graduates with a permanent contract. This remarkable result may be explained by the fact that university graduates often have jobs with substantial learning content such as trainee posts (hospitals), traineeships (banks or insurers) or PhD positions (Try, 2004). Employers may screen these graduates for ability, motivation and discipline. Moreover, for graduates these positions may be a stepping stone to a permanent job. The unique job aspects of university graduates may explain why the share of temporary contracts among university graduates exhibits almost no co-movement with the business cycle (see Figure 1b). However, for the other job aspects, UE graduates remain worse off with a fixed-term contract. They get considerably less training and earn significantly less than graduates in permanent jobs.

\section{Figure 2}

Impact of a fixed-term contract on job aspects of graduates by level of education, graduates with permanent jobs are the reference group, marginal effects based on logistic regression analyses, 2002-2008

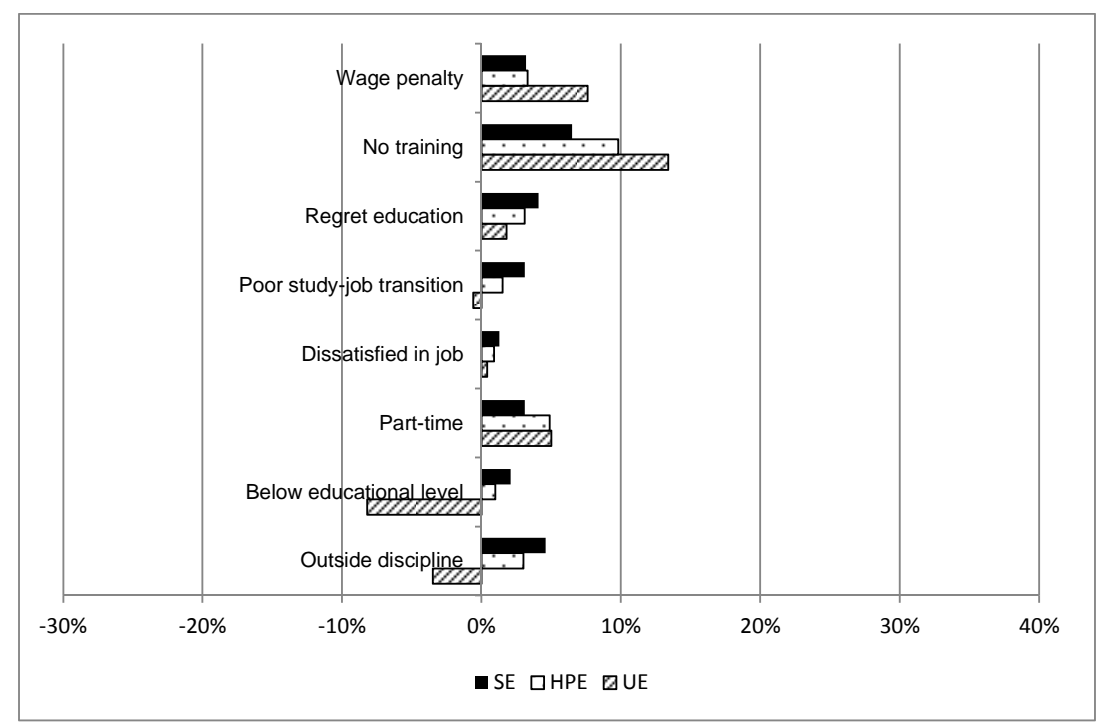

Source: ROA graduates surveys (SIS)

Notes:

- $\mathrm{SE}=$ upper secondary education (excl. apprentices); HPE = higher professional education; UE = university education.

- Almost all marginal effects of the explanatory factors in Figures 2 en 3 are statistical significant at the 1\% of significance. The remaining effects are significant at the 5 or $10 \%$ level.

- The following control variables have been used in the analyses: gender, ethnicity, interaction gender*ethnicity, age, age squared, final exam result, level of the course (for SE only), work region and survey year.

\section{Graduates in temporary agency jobs}

We conduct analyses for temporary agency workers in the same way as for fixed-term workers. Figure 3 presents the marginal effects on several job aspects for graduates with a temporary agency contract instead of a

\footnotetext{
${ }^{6}$ Part-time work is another aspect of so-called 'atypical work' that may indicate a disadvantageous situation for the worker (De Grip et al., 1997).
} 
permanent contract. At the upper secondary (SE) level, temporary agency work is significantly positively related to all unfavourable job aspects. In addition, it can be concluded that SE graduates with a temporary agency contract are worse off in terms of their gross hourly wage, since they earn 14 percent less than SE graduates with a permanent contract. This is also worse than for SE graduates with a fixed-term contract (see Figure 2).

At the higher professional (HPE) level, graduates in temporary agency jobs are worse off on all eight job aspects compared to graduates in permanent jobs. This is similar to the results for fixed-term workers. Graduates in temporary agency jobs are particularly more likely to work outside their discipline and below their level, and are trained less often than permanent workers of this level, as can be concluded from the high marginal effects $(25,21$ and 15 percent, respectively) relative to those for SE graduates. Moreover, they earn 18 percent less per month than permanent workers, whereas fixed-term workers earn only 3 percent less than permanent workers (see Figure 2).

At the university (UE) level, the job aspects of graduates in temporary agency jobs are considerably worse than similar aspects of graduates in permanent and fixed-term jobs. Unlike some job aspects for fixed-term graduates at the university level, this holds for all job aspects. The effects on the unfavourable job aspects of UE graduates in temporary agency jobs are usually even stronger compared to those of HPE graduates. University graduates in temporary agency jobs are particularly more likely to work below their educational level than university graduates in permanent jobs (40 percent). Finally, there is a vast difference in gross hourly wages between temporary agency jobs and permanent jobs for UE graduates. The former group of jobs pay 27 percent less per month than the latter, which is also considerably less than temporary agency jobs at the HPE level and fixed-term workers at the UE level (see Figure 2).

\section{Figure 3}

Impact of a temporary agency contract on job aspects of graduates by level of education, graduates with permanent jobs are the reference group, marginal effects based on logistic regression analyses, 2002-2008

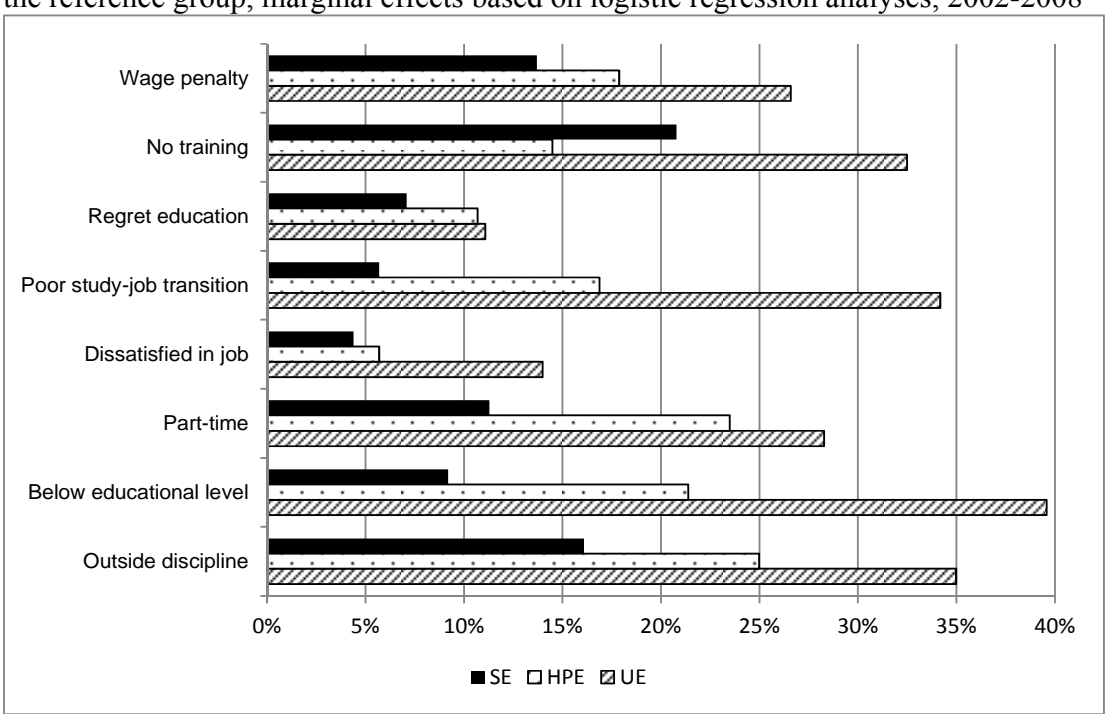

Source: ROA graduates surveys (SIS)

Notes: See Figure 2.

\section{Explanations for Flexible Contracts among Recent Graduates}

Given the relatively bad performance of flexible contracts on various job match indicators as shown in the previous section, we may ask ourselves why recent graduates enter into flexible contracts. To answer this question we first refer to explanations concerning the personal characteristics of graduates (the 'supply side' of the labour market), and second to labour market circumstances, which are more or less employer-driven (the 'demand side').

On the supply side, it can be safely assumed that graduates will usually prefer permanent over flexible jobs. They can signal motivation, ambition and ability (Spence, 1973) to obtain a permanent instead of a temporary job, since employers will be more willing to fill permanent slots with highly able graduates. The employer can offer permanent contracts to the most able graduates or those that meet the required standards. Therefore, 
graduates' final exam grades can be used as an explanatory factor for their probability of entering into flexible jobs.

However, flexible jobs may also serve as a genuine stepping stone toward a higher level permanent job. Following a traineeship or working towards a $\mathrm{PhD}$ may be highly rewarded in their later career. These positions, which often go together with temporary contracts, are generally open to high ability graduates with good grades. Try (2004) indeed finds evidence that recent graduates consider some flexible jobs (in particular, research fellowships) as a good investment opportunity. Apart from that, recent graduates can use flexible jobs for screening interesting jobs or employers, choose for flexible jobs if they like variation in their work, or bridge the time to another (permanent) job (Houseman, 2001).

Given the graduates' preference for permanent contracts they should, according to the theory of compensating wage differentials (Rosen, 1986), only accept a temporary job if they receive a higher salary than that of permanent workers. Although this theory probably does not to hold in an absolute sense (see below) graduates who are more willing to take risks are more likely to accept temporary contracts given the lower wage differential they expect to get from employers for higher job insecurity. It may be expected that graduates who are least risk averse will require the smallest compensation and will have the highest probability to end up in flexible work (Dohmen et al., 2011). In the empirical analysis, we will use the willingness to take risks of graduates as another independent variable to explain the probability to enter into flexible contracts.

On the demand side of the labour market, it follows from dual labour market theory that flexible work may be related to so-called 'bad jobs' in the secondary labour market segment (Doeringer and Piore, 1971; Reich et al., 1973; Rebitzer and Taylor, 1991). Young people, including recent graduates, must often accept temporary rather than permanent jobs when they are faced with high youth unemployment rates (Treu, 1992). A high incidence of flexible employment in particular fields of study may therefore be a manifestation of low labour demand and a weak labour market position for those who graduated in these fields (De Grip et al., 1997). This may also hold for those groups that traditionally have a weak position in the labour market in terms of high unemployment and loose attachment to the labour market. These groups include young people entering the labour market as well as immigrant, low-skilled and female workers. They may move from one flexible job to another, interrupted by periods of unemployment or inactivity.

A high incidence of flexible jobs among recent graduates can also be explained by the insider-outsider model (Bentolila and Dolado, 1994; Lindbeck and Snower, 2002). Permanent workers (insiders) dominate the labour unions and will make sure that their terms of employment are guaranteed as much as possible relative to the outsiders. These outsiders are the groups of people with a weak link to the labour market, including new entrants like recent graduates. Unfavourable job aspects for the outsiders' jobs may include temporary contracts and low wages $^{7}$ as well as detrimental working conditions, more work accidents, lack of training opportunities and higher job strain (Houseman, 2001; Zijl, 2006). Two empirical studies specifically analyse the labour market position of recent graduates, and point to the less attractive aspects of temporary jobs among these graduates. Wieling and Borghans (2001) show that the incidence of temporary work for Dutch graduates of different educational programs depends on lack of labour demand for (or alternatively excess supply of) people educated in these programs. They find that working for a low wage, below the educational level (i.e., the graduate is overeducated) or outside the occupational domain are other job aspects associated with temporary jobs that indicate a weak labour market position for recent graduates. Also Try (2004) shows that temporary jobs are widespread among recent graduates in Norway, and that temporary jobs are generally associated with working below the educational level and for lower wages.

Another important motive for employers to offer graduates a temporary contract may be the screening motive (Winkler, 1987). If unemployment is high for graduates with particular degrees, employers can allow themselves to screen recent graduates with these degrees more intensively by postponing a permanent contract offer. Temporary employment agencies may even be better than the employer at gathering important information about the skills and motivation of temporary agency workers by training and testing them (Autor, 2004). Based on dual labour market theory, insider-outsider theory and screening theory we will include both the unemployment rate per education type and the attachment of educations to occupations as independent variables to explain the

\footnotetext{
${ }^{7}$ Compensation for temporary workers is indeed lower than for permanent workers with the same background characteristics and occupying the same kind of job (European Commission, 2003). These so-called wage penalties vary from ca. 5 percent in France, Germany, Belgium and Austria to more than 15 percent in the Netherlands.
} 
probability of getting a flexible job. The higher the unemployment rate and the lower the attachment to occupations, the higher the probability of a flexible job is expected to be for graduates with a particular level and field of education.

The minimization of adjustment costs of the workforce can be seen as the main motive for employers to offer temporary contracts. From the theory of adjustment costs (Hamermesh and Pfann, 1996) we can infer that employers may be more likely to enter into temporary contracts with graduates educated in fields susceptible to large employment variations. These variations can stem from the business cycle as well as from other factors, such as changes in government budgets for health care or education. Employers indeed report that fluctuations in the demand for goods and services (like seasonal work) and temporary absences of incumbent staff due to for example holidays or sickness are the most prevalent motives to hire flexible workers (Houseman, 2001; Storrie, 2002). Employers may also choose to fill a position temporarily to bridge the time until a worker with the appropriate skills is found, and hire expertise required for specific projects. To account for business cycle and other variations in employment we will include an explanatory variable that measures employment variation over time for graduates with different educational backgrounds. The higher the employment variation for a particular level and field of education, the higher the probability of a flexible job is expected to be for graduates with the respective educational background.

\section{Explanatory Model for Flexible Work among Recent Graduates}

Based on our review of the literature, we distinguish between two main factors at the 'supply' side and three main factors at the 'demand' side of the labour market to explain the probability of recent graduates entering into flexible jobs. ${ }^{8}$ First, there are supply or 'push' factors, based on several personal characteristics in our logistic regression analyses. The final exam result and the willingness to take risks are the two main explanatory variables measured at the individual level as proxies for ability and preference of graduates, respectively. Gender and age are merely control variables. It is to be expected that the more able and more risk averse graduates are more likely to obtain a permanent job. Second, there are demand or 'pull' factors, mainly based on labour market circumstances. We include explanatory variables on labour market circumstances to analyse to what extent recent graduates are more or less forced into flexible jobs. The most important one is the unemployment rate of the labour force, differentiated by level and field of study. The two other explanatory variables with respect to labour market circumstances are the attachment of the educational background to a particular occupational domain, measured by the labour market dispersion of types of education, and the employment variation that graduates face on the labour market given their level and field of study. These three factors are measured for each of the more than 85 educational types in upper secondary and higher education. ${ }^{9}$ As has been argued in the previous section, higher labour market dispersion may point to a lower attachment to occupations and a worse labour market position, which is expected to result into a higher share of recent graduates working on a temporary basis. Moreover, we expect that a larger employment variation increases the incentives for employers to appoint graduates on temporary contracts. We also include the work region of graduates and the survey year to correct for regional differences or general changes over time in the labour market position of graduates. Table A.1 of the Annex shows the summary statistics of the data set used in this section. ${ }^{10}$

Table 1 presents the marginal effects of the explanatory variables on the probability of having a fixed-term or a temporary agency job. The marginal effects have been estimated with logistic regression analyses. The reference group consists of recent graduates with a permanent contract. The table focuses on the marginal effects of the explanatory variables on the probability of working in either a fixed-term job or a temporary agency job. The control variables included are gender, ethnicity, age, level of education, work region and survey year.

There are, of course, sensible alternative estimation models. Next to the one presented in this paper, we have estimated the regressions using multinominal and ordered logit models. Intuitively, it would make sense to order the outcomes from permanent via fixed-term job to temporary agency job, with unemployment as an additional worst alternative. While this might suggest a logical order in the different job options ranging from a permanent job to being unemployed, the estimation results of the ordered logit model showed that this assumption is

\footnotetext{
${ }^{8}$ See the Annex for more details on the measurement of the five factors.

${ }^{9}$ See ROA (2009) for an overview of these educational types.

${ }^{10}$ We have only used data from 2002 to 2008 , since some important explanatory variables were missing for the years before.
} 
violated. The alternative, using unordered end-nodes, is the multinominal logit analysis. Given that the estimates were strongly comparable to the ones from the simple logit model, which can be seen as robustness checks, we choose to only present the estimates from the latter. In addition, university graduates (UE) have higher probabilities of a fixed-term job (compared to a permanent one), which seems to follow its own time trend (see Figure 1b). The reason for this is that in UE it is more common to have fixed-term contracts, like trainee posts or $\mathrm{PhD}$ positions. The analyses in Table 1 have also been performed including interaction effects between UE and year dummies, which resulted in almost equal estimates.

Table 1 presents three regression analyses. In column (1), we include the graduates' final exam result and the unemployment rate per educational type as the main explanatory variables. The other variables are considered as control variables. The final exam result has a significantly negative effect on the probability of both fixed-term and temporary agency contracts. For HPE graduates, there is no additional effect of the final exam result. This means that higher grades decrease the probability of a flexible job for SE and HPE graduates. The same holds for UE graduates in temporary agency jobs. These findings in general confirms our expectations.

However, for UE graduates in fixed-term jobs the marginal effect of final exam result is significantly positive, indicating that university graduates with higher grades are more prone to particular fixed-term relationships. Interestingly, the results differ substantially for the probability of graduates on fixed-term and temporary agency jobs at the university level. While university graduates in several fields of study have a rather low probability of accepting a temporary agency contract, the same cannot be concluded for university graduates with a fixed-term contract. Additional analyses show (not included in the table) that university graduates of almost all fields of study are relatively likely to have a fixed-term contract. This is especially true for those obtaining a degree in medical science. Only university graduates with a degree in economics and law have a relatively small probability of a fixed-term contract. Fixed-term contracts might be highly prevalent among recent university graduates not because these graduates face a poor labour market situation, but rather because they pursue positions that are more likely to include fixed-term contracts, like trainee posts (hospitals) or $\mathrm{PhD}$ positions (universities). ${ }^{11}$

For the other personal characteristics, Table 1 shows that female graduates and graduates from minority groups have a larger probability of fixed-term and temporary agency jobs. As has been argued before, in general both types of flexible work may point to a disadvantageous labour market situation of graduates, since they are related to several negative job aspects and since graduates usually prefer permanent over temporary jobs. For females and minority groups, this confirms the often reported result in empirical studies that their labour market position is relatively weak.

To account for differences in the labour market position of educational programs, we also include the unemployment rates of the educational types for the years between 2002 and 2008 as explanatory variables for the incidence of flexible work among graduates. According to expectations, graduates in educational programs exposed to high unemployment have a higher probability of engaging in both types of flexible work. This holds even more strongly for university graduates. University graduates (UE) are thus less likely to obtain a permanent contract when they face a poor labour market situation than graduates at the upper secondary level of education (SE).

For the other labour market variables Table 1 shows that the incidence of flexible work is low in the Western part of the Netherlands, and particularly high in the North. This result can be explained by the fact that the labour market is loosest in the North (i.e., the most rural part), and tightest in the West (i.e., the most urbanized part) of the Netherlands. The estimated effects for the year dummies suggest that the business cycle impacts the probability of flexible work.

\footnotetext{
${ }^{11}$ See also Try (2004) on this point.
} 


\section{Table 1}

The impact of personal and labour market characteristics on the probability of having a fixed-term or temporary agency job, graduates with permanent jobs are the reference group, marginal effects after logistic regressions, 2002-2008

Column (1)

Type of contract:
Column (2): Column (1) plus

labour market dispersion and employment variation
Column (3): Column (2) plus willingness to take risks, only 2008 data

\begin{tabular}{|c|c|c|c|c|c|c|}
\hline \multirow[t]{2}{*}{ Type of contract: } & Fixed-term & Temp. agency & Fixed-term & Temp. agency & Fixed-term & Temp. agency \\
\hline & Coef. & Coef. & Coef. & Coef. & Coef. & Coef. \\
\hline \multicolumn{7}{|l|}{ Personal characteristics } \\
\hline Female & $0.047 * * *$ & $0.014 * * *$ & $0.040 * * *$ & $0.020 * * *$ & $0.062 * * *$ & 0.012 \\
\hline Immigrant & $0.043 * * *$ & $0.042 * * *$ & $0.044 * * *$ & $0.043 * * *$ & 0.015 & $0.104 *$ \\
\hline Female*Immigrant & -0.000 & $0.022 * *$ & 0.000 & $0.019^{* *}$ & 0.076 & 0.007 \\
\hline Age & $0.035 * * *$ & $-0.024 * * *$ & $0.036 * * *$ & $-0.017 * * *$ & 0.045 & -0.037 \\
\hline Age*Age & $-0.001 * * *$ & $0.000 * * *$ & $-0.001 * * *$ & $0.000 * *$ & -0.001 & 0.001 \\
\hline HPE & 0.024 & -0.001 & $0.208 * * *$ & $0.148 * * *$ & $0.498 * *$ & 0.182 \\
\hline UE & 0.013 & $-0.055 * * *$ & $0.530 * * *$ & $0.435 * * *$ & $0.510 * *$ & 0.239 \\
\hline Final Exam Result & $-0.017 * *$ & $-0.023 * * *$ & -0.004 & $-0.014 * * *$ & 0.051 & 0.009 \\
\hline$* \mathrm{HPE}$ & 0.004 & -0.000 & 0.000 & -0.003 & -0.026 & -0.007 \\
\hline$* \mathrm{UE}$ & $0.040 * * *$ & 0.001 & $0.033 * * *$ & -0.005 & 0.031 & -0.009 \\
\hline \multicolumn{5}{|c|}{ Willingness to Take Risks (2008) } & $-0.020 *$ & -0.003 \\
\hline * HPE & & & & & 0.014 & 0.003 \\
\hline \multicolumn{5}{|l|}{ *UE } & 0.017 & 0.004 \\
\hline \multicolumn{7}{|c|}{ Labour market characteristics } \\
\hline North & $0.085 * * *$ & $0.078 * * *$ & $0.080 * * *$ & $0.075 * * *$ & 0.050 & $0.077 * *$ \\
\hline East & $0.034 * * *$ & $0.010^{* * *}$ & $0.030 * * *$ & $0.009^{* *}$ & 0.001 & 0.008 \\
\hline West & $-0.024 * * *$ & $-0.01 * * * 5$ & $-0.025 * * *$ & $-0.016 * * *$ & $-0.085 * * *$ & -0.013 \\
\hline Year dummy's & $0.177 * * *$ & $0.065 * * *$ & $0.182 * * *$ & $0.069 * * *$ & & \\
\hline 2004 & $0.183 * * *$ & $0.098 * * *$ & $0.191 * * *$ & $0.108 * * *$ & & \\
\hline 2005 & $0.210 * * *$ & $0.124 * * *$ & $0.216 * * *$ & $0.131 * * *$ & & \\
\hline 2006 & $0.232 * * *$ & $0.137 * * *$ & $0.235 * * *$ & $0.136^{* * *}$ & & \\
\hline 2007 & $0.210 * * *$ & $0.106 * * *$ & $0.212 * * *$ & $0.104 * * *$ & & \\
\hline 2008 & $0.224 * * *$ & $0.105 * * *$ & $0.224 * * *$ & $0.100 * * *$ & & \\
\hline Unemployment Rate & $0.014 * * *$ & $0.008 * * *$ & $0.010 * * *$ & $0.004 * * *$ & -0.006 & -0.009 \\
\hline * $\mathrm{HPE}$ & 0.002 & 0.002 & 0.003 & $0.005^{* * *}$ & 0.016 & 0.016 \\
\hline$* U E$ & $0.008 * * *$ & $0.013 * * *$ & $0.013 * * *$ & $0.012 * * *$ & 0.029 & $0.053 * * *$ \\
\hline \multicolumn{3}{|l|}{ Labour Market Dispersion } & $0.004 * * *$ & $0.003 * * *$ & $0.007 *$ & $0.004 *$ \\
\hline \multicolumn{3}{|l|}{ *HPE } & $0.003 * * *$ & -0.001 & -0.003 & -0.003 \\
\hline$* \mathrm{UE}$ & & & $-0.006 * * *$ & $-0.002 * * *$ & -0.003 & -0.001 \\
\hline \multicolumn{3}{|l|}{ Employment Variation } & $0.186 * * *$ & $0.175 * * *$ & 0.319 & 0.200 \\
\hline & & & $-0.212 * * *$ & $-0.152 * * *$ & $-0.591 * *$ & -0.220 \\
\hline \multicolumn{2}{|l|}{ *UE } & & $-0.453 * * *$ & $-0.283 * * *$ & $-0.660 * *$ & $-0.349^{*}$ \\
\hline Number of obs. & 89,342 & 60,506 & 89,342 & 60,506 & 3,203 & 2,120 \\
\hline Pseudo R2 & 0.027 & 0.047 & 0.035 & 0.054 & 0.045 & 0.072 \\
\hline
\end{tabular}

Notes:

- $* * *=1 \%$ of significance, $* *=5 \%$ level of significance, $*=10 \%$ level of significance;

- Reference group for the dependent variable consists of recent graduates with a permanent contract;

- $\mathrm{SE}=$ upper secondary education (excl. apprentices); HPE = higher professional education; UE = university education.

- Reference groups for the explanatory variables are male, native, SE, South and 2002. 
In Column (2) we add two more labour market characteristics, namely labour market dispersion and employment variation. Apart from unemployment, high labour market dispersion is another indicator for a weak labour market position of recent graduates from particular fields of education. Column (2) shows that the effect of labour market dispersion on the share of fixed-term contracts is significantly positive. Thus, as the occupations for graduates of a particular type of education grow more dispersed on the labour market, the probability that graduates accept a fixed-term contract increases. The more dispersed occupations on the labour market for graduates of a particular type of education are, the larger their probability of having a fixed-term contract. Graduates' opportunity to choose from a wider range of alternative occupations comes at the cost of lower job security. For HPE graduates with fixed-term contracts this effect is even stronger, while the interaction effect is significantly negative for UE graduates. For UE graduates with fixed-term contracts, the net effect is close to zero. For temporary agency contracts, we find positive effects at all three levels.

Employers may be more inclined to enter into temporary contracts when uncertainties regarding production volume and labour demand are larger. The employment variation by educational type is dependent on the employment changes (including business cycle effects) of both industries and occupations in which the educational types are most relevant. Apart from the indicator for employment variation by educational type, we include year dummies as the usual control variables for cyclical variations. Column (2) shows that if graduates from upper secondary education (SE) have a diploma in a field of study that is more subject to employment variations, they are significantly more likely to have either a fixed-term or a temporary agency contract. For HPE and UE graduates, the interaction effect of employment variations is significantly negative. The net effect is significantly negative for UE. From these results it can be concluded that employers primarily use graduates from upper secondary education to adapt to cyclical changes in labour demand.

Finally, column (3) shows the effect of including the willingness to take risks as an additional personal characteristic. It may be expected that recent graduates who are more willing to take risks are also more likely to have a temporary contract. We only have this variable for a particular share of graduates in the 2008 survey. We do not find empirical evidence for the expected relationship for the probability of a fixed-term job, or for the probability of a temporary agency job. On the contrary, we find that willingness to take risks has a small negative effect (which is, however, only marginally significant at the levels reported in the table) on the probability of having a fixed-term contract, indicating that graduates who are more prone to take risks are less likely to have a fixed-term contract relative to a permanent contract. ${ }^{12}$ Graduates' willingness to take risks doesn't seem to play a significant role in the selection of the type of contract when graduates enter the labour market.

\section{Conclusions}

This papers shows that recent graduates in the Netherlands often accept a fixed-term or temporary agency job, yet usually not because of their own preferences. Graduates with a greater dislike for unsecure jobs have at least the same probability of accepting a temporary contract as other graduates. The temporality of a job seems to be perceived as a less attractive job characteristic that many recent graduates have to accept out of necessity when the labour market situation deteriorates. A flexible job is strongly associated with several other less favourable job aspects: there is a wage penalty on working in these jobs, graduates work more often below their educational level (i.e. are overeducated) or outside their occupational domain more often when accepting a flexible job, and they are more likely to regret their choice of study than those who get a permanent job. We show that recent graduates, when compared to the total group of employees, are often used as a buffer for dealing with fluctuations in the demand for personnel.

In this paper, we discuss reasons for a high incidence of flexible work among graduates in particular fields of study. Our explanatory model reveals that graduates who, due to their educational background, face higher unemployment or lower attachment to occupations, have a higher probability of entering into a flexible job. Employers will take more time to screen graduates in fields of study with higher unemployment rates or with a loose attachment to the specific occupations in their companies. Moreover, recent graduates in fields of study

\footnotetext{
${ }^{12}$ Using alternative risk measures (see Annex A) still does not yield other results for the impact of willingness to take risks. This also holds for regression analyses that exclude other explanatory factors or include only graduates' willingness to take risks.
} 
that are more heavily subject to employment variations are significantly more likely to have a fixed-term or temporary agency job. This suggests that employers are reluctant to enter into permanent contracts when product demand is low and uncertainty in labour demand is high. We find evidence that personal characteristics of graduates matter to some extent: graduates with higher average grades get a permanent contract more often than graduates with lower grades. Employers can use final exam grades as a screening instrument for permanent job offers to reduce the risk of a bad job match and to achieve high firm productivity. Only at university level do higher grades result into a greater likelihood of getting a fixed-term instead of a permanent job. Since our analyses show that university graduates are better off with fixed-term rather than permanent contracts with respect to the job match when entering the labour market and that their selection into temporary jobs is less dependent on the business cycle than for graduates at lower levels, we conclude that fixed-term jobs at academic level such as trainee posts in hospitals or PhD positions at universities may offer a stepping stone for a career.

Our main conclusion is that the selection of recent graduates into either permanent or flexible jobs occurs primarily on the demand side of the labour market, i.e. choices are made by employers rather than by graduates. This may give rise to some worries. In bad economic times the share of flexible jobs becomes higher, which leads to less human capital investments in young people, who have a long career ahead, and possibly to scarring effects. Recently, the Dutch government allowed employers by law to appoint people younger than 27 years old four (instead of formerly three) subsequent times on a temporary contract. The government expects from this policy measure that young workers will have more chances to get a permanent contract. Furthermore, in the Netherlands, as in many other European countries, there is a generally felt urgency to allow more flexibility on the labour market. Our paper points at a risk of underinvestment in human capital if temporary contracts are a substitute for permanent contracts. On the other hand, without flexible jobs unemployment may even be higher since many companies do not dare to give permanent contracts during uncertain circumstances. Moreover, the paper indicates that some temporary jobs might match better the graduates' competences and ambitions than permanent jobs. Therefore, both employer associations and labour unions should look whether flexible jobs, in particular those for recent graduates offer enough incentives to invest in training on the job. If not, they could take several measures when negotiating collective labour agreements, like including a better use of the available training funds at industry level, in particular for recent graduates. Furthermore, they could extend the maximum duration period of the labour contracts for young people beyond the legal period of three years or agree on a minimum period for the duration of particular short-term labour contracts to increase the incentives to invest in training.

\section{References}

Addison, J.T. and C.J. Surfield (2007), 'Atypical work and Pay', Southern Economic Journal, Vol. 73, pp. 10381065.

Addison, J.T. and C.J. Surfield (2009a), 'Does atypical work help the jobless? Evidence from a CAEAS/CPS cohort analysis’, Applied Economics, Vol. 41, pp. 1077-1087.

Addison, J.T. and C.J. Surfield (2009b), ‘Atypical work and Employment Continuity', Industrial Relations, Vol. 48 , pp. $655-683$.

Allen and Van der Velden (2007, Ed.), The Flexible Professional in the Knowledge Society: General Results of the REFLEX Project, Research Centre for Education and the Labour Market, Maastricht University.

Autor, D. (2004), 'Labor Market Intermediation: What Is It, Why It Is Growing', NBER Reporter, Research Summary, Fall: http://www.nber.org/reporter/fall04/autor.html.

Autor, D. and S. Houseman (2005), 'Temporary Agency Employment as a Way out of Poverty?', NBER Working Papers, nr. 11742, National Bureau of Economic Research, Cambridge, MA

Autor, D.H. and S.N. Houseman (2010), 'Do Temporary-Help Jobs Improve Labor Market Outcomes for LowSkilled Workers? Evidence from "Work First", American Economic Journal: Applied Economics, Vol. 2, pp. 96-128. 
Bentolila, S. and J.J. Dolado (1994), 'Labour Flexibility and Wages: Lessons from Spain', Economic Policy, Vol. 9, pp. 55-99.

Booth, A.L., M. Francesconi and J. Frank (2002), 'Temporary Jobs: Stepping Stones or Dead Ends?', Economic Journal, Vol. 112, pp. F189-F213.

Borghans, L. and H. Heijke (1998), 'Flexibility and the Structure of the Dutch Labour Market', in: H. Heijke, L. Borghans (eds), Towards a Transparent Labour Market for Educational Decisions, Ashgate, Aldershot/Brookfield USA/Singapore/Sydney, pp. 119-150.

Cörvers, F., A. Dupuy, S. Dijksman, B. Kriechel and R. Montizaan (2010), Methodiek arbeidsmarktprognoses en -indicatoren 2009-2014, ROA-TR-2010/5, Research Centre for Education and the Labour Market, Maastricht University.

Cörvers, F., R. Euwals, A. de Grip (2011), Labour Market Flexibility in the Netherlands, CPB-ROA publication, The Hague.

De Grip, A., J. Hoevenberg and E. Willems (1997), 'Atypical Employment in the European Union', International Labour Review, Vol. 136, pp. 49-71.

Dekker, R. (2007), Non-standard employment and mobility in the Dutch, German and British labour market, Thesis, Universiteit van Tilburg.

Doeringer, P. and M. Piore (1971), Internal Labor Markets and Manpower Analysis, Lexington Books, Heath, Lexington.

Dohmen, T., A. Falk, D. Huffman, U. Sunde, J. Schupp and G.G. Wagner (2011), 'Individual Risk Attitudes: Measurement, Determinants and Behavioral Consequences', Journal of the European Economic Association, Vol. 9, pp. 522-550.

European Commission (2003), Employment in Europe 2003: Recent Trends and Prospects, Luxembourg.

Hamermesh, D.S. and G.A. Pfann (1996), 'Adjustment Costs in Factor Demand', Journal of Economic Literature, Vol. 34, pp. 1264-1292.

Houseman, S.N. (2001), 'Why Employers Use Temporary Staffing Arrangements: Evidence from an Establishment Survey’, Industrial and Labor Relations Review, Vol. 55, pp.149-170.

Houseman, S.N. and A.E. Polivka (2000), 'The implications of flexible staffing arrangements for job security', in D. Neumark (Ed.), On the Job: Is Long-Term Employment a Thing of the Past?, Russell Sage Foundation, New York, pp. 427-62.

Lindbeck, A. and D.J. Snower (2002), The insider-outsider theory: A survey, Discussion paper No 534, IZA, Bonn.

Rebitzer, J.B. and L.J. Taylor (1991), 'A Model of Dual Labor Markets when Product Demand is Uncertain', Quarterly Journal of Economics, Vol. 106, pp. 1373-83.

Reich, M., D.M. Gordon and R.C. Edwards (1973), ‘A Theory of Labor Market Segmentation', American Economic Review, Vol. 63, pp. 359-365.

ROA (2009), De arbeidsmarkt naar opleiding en beroep tot 2014, ROA-R-2009/5, Research Centre for Education and the Labour Market, Maastricht University.

Spence, M. (1973), ‘Job Market Signaling', Quarterly Journal of Economics, Vol. 87, pp. 355-374. 
Storrie, D. (2002), Temporary Agency Work in the European Union, European Foundation for the Improvement of Living and Working Conditions, Dublin.

Treu, T. (1992), 'Labour flexibility in Europe', International Labour Review, Vol. 131, pp. 497-512.

Try, S. (2004), 'The Role of Flexible Work in the Transition from Higher Education into the Labour Market', Journal of Education and Work, Vol. 17, pp. 27-45.

Wieling, M. and L. Borghans (2001), 'Discrepancies between Supply and Demand and Adjustment Processes in the Labour Market', Labour, Vol. 15, pp.33-56.

Winkler, D.R. (1987), 'Screening Models and Education'; in G. Psacharopoulos (ed.), Economics of Education: Research and Studies, Pergamon Press, Oxford, pp. 287-291.

Zijl, M. (2006), Economic and Social Consequences of Temporary Employment, Academic thesis, Thela Thesis Publising, Amsterdam.

Zijl, M., G.J. van den Berg and A. Heyma (2004) Stepping stones for the unemployed: the effect of temporary jobs on the duration until regular work, IZA Discussion Paper \#1241. 


\section{Annex}

Table A.1

Summary statistics of the variables used in the empirical analyses of Section 5

\begin{tabular}{|c|c|c|c|}
\hline Variable & Mean & Min & $\operatorname{Max}$ \\
\hline Permanent contract & 0.584 & 0 & 1 \\
\hline Flexible contract & 0.416 & 0 & 1 \\
\hline Final Exam Result & 7.273 & 6 & 8.5 \\
\hline Willingness to Take Risks (2008) & 6.134 & 0 & 10 \\
\hline Secondary Education (SE) & 0.206 & 0 & 1 \\
\hline Higher Professional Education (HPE) & 0.501 & 0 & 1 \\
\hline University Education (UE) & 0.293 & 0 & 1 \\
\hline Female & 0.561 & 0 & 1 \\
\hline Immigrant & 0.093 & 0 & 1 \\
\hline Age & 24.523 & 15 & 39 \\
\hline Unemployment Rate & 3.522 & 0 & 20.73 \\
\hline Labour Market Dispersion & 9.575 & 1.22 & 37.39 \\
\hline Employment Variation & 1.033 & 0.51 & 1.68 \\
\hline \multicolumn{4}{|l|}{ Work region } \\
\hline North & 0.093 & 0 & 1 \\
\hline East & 0.181 & 0 & 1 \\
\hline West & 0.516 & 0 & 1 \\
\hline South & 0.210 & 0 & 1 \\
\hline \multicolumn{4}{|l|}{ Year dummy's } \\
\hline 2002 & 0.152 & 0 & 1 \\
\hline 2003 & 0.120 & 0 & 1 \\
\hline 2004 & 0.144 & 0 & 1 \\
\hline 2005 & 0.148 & 0 & 1 \\
\hline 2006 & 0.146 & 0 & 1 \\
\hline 2007 & 0.152 & 0 & 1 \\
\hline 2008 & 0.138 & 0 & 1 \\
\hline
\end{tabular}

Source: ROA graduates surveys (SIS), 2002-2008 


\section{Overview of the measurement of the main explanatory factors}

\section{Final exam result (FER)}

The final exam result of a graduate is the average grade in the exam year of secondary or tertiary education. A higher grade indicates better performance.

\section{Willingness to take risks (WTR)}

Willingness to take risks is measured by asking graduates to make a global assessment, specifically: 'How willing are you to take risks, in general?' (for more information, see Dohmen et al. (2011)). Respondents rate their willingness to take risks on a scale from 0 to 10 (an eleven-point scale). In addition to the question on willingness to take risks 'in general', responses to questions on willingness to take risks concerning financial matters and career were also used to perform some robustness checks.

\section{Unemployment rate (UR)}

Unemployment rate for each educational type is calculated as the percentage of unemployed people for this educational type divided by the total number of people with the respective educational background in the labour force. The data source is the Labour Force Survey of Statistics Netherlands. The unemployment rates per educational type are calculated for each year separately.

\section{Labour market dispersion (LMD)}

Labour market dispersion is an indicator of the spread of the types of education across occupations. The indicator is similar to the Gini-Hirshman index (Cörvers et al., 2010). If all graduates of a particular educational type work in one occupation, then the index is equal to 1 . The higher the indicator, the more an educational type is dispersed over different occupations. A larger dispersion points to a weaker position in a specific occupational domain, although the labour market risk is also more spread out amongst different occupations (Borghans and Heijke, 1998). Since labour market dispersion of educational types does not reveal much variation over time, it has been calculated for the last available year.

\section{Employment variation (EV)}

Employment variation across educational types is measured in three steps. First, the extent to which employment in sectors of industry varies from year to year is estimated. Time series from 1987 to 2008 are used. Second, the sensitivity of employment in occupations to employment variations per industry is measured. Third, the variation indicators for occupations are weighted by the shares of employment of these occupations in total employment of each educational type. The average value of employment variation is normalized to 1. A higher value indicates greater variation in employment.

The indicator of employment variation (which includes cyclical sensitivity) is determined over a period of 20 years, using the Labor Force Surveys from 1987-2008. It determines the occupation and sector specific responses of employment to business cycle fluctuations, budget changes by the government, and other economic shocks. It is computed for 127 occupational groups. We use the occupation specific indicator that captures the variation by sector, weighted by the importance of the sector for the occupation and the fluctuation of the occupation within a sector. The indicator is determined as follows (Cörvers et al., 2010):

$$
E V_{o t}=\sum_{s} \frac{E_{o s t}}{E_{s t}} \alpha_{o s t} E V_{s t}
$$

$E V_{o t}=$ employment variation of occupation $o$ at time $t$

$E_{\text {ost }}=$ number of persons employed in occupation $o$ in sector $s$ at time $t$

$E_{s t}=$ number of persons employed in sector $s$ at time $t$

$\alpha_{o s}=$ extent to which employment in occupation varies with changes in employment in sector $s$

$E V_{s t}=$ sectoral employment variation

Where 
$E V_{s t}=100 * \sum_{t} \frac{\left|E_{s t}-\bar{E}_{s t}\right|}{E_{s t}}$

$\bar{E}_{s t}=\frac{E_{s t-1}-E_{s t+1}}{2}$

$E V_{s t}$ is estimated on Labour force employment data from 1987-2008

$E V_{o t}$ is estimated on Labour Force Survey data from 1996-2008 